\title{
Biohydrogen production by bacteria isolated from manures of three different bovines using synthetic starch wastewater as substrate
}

\author{
Jemilatu Omuwa Audu ${ }^{1}$ and Mohd Firdaus Abdul-Wahab ${ }^{2 \star}$ \\ ${ }^{1}$ Department of Biosciences and Health Sciences, Faculty of Biosciences and Medical Engineering, Universiti Teknologi \\ Malaysia, 81310 UTM Skudai, Johor, Malaysia. \\ ${ }^{2}$ Nanoporous and Mesoporous Materials for Biological Applications Research Group (NAMBAR), Sustainability \\ Research Alliance, Universiti Teknologi Malaysia, 81310 UTM Skudai, Johor, Malaysia. \\ Email: firdausw@utm.my
}

Received 26 August 2013; Received in revised form 20 September 2013; Accepted 10 October 2013

\begin{abstract}
Aims: This study aimed at investigating the various hydrogen-producing bacteria isolated from three different bovine manure samples (dairy cow, feedlot cow and free grazing cow manures).

Methodology and results: Nutrient broth (NB) and Reinforced Clostridium medium (RCM) broth were used for the isolation of facultative and strict anaerobic bacteria. The isolates were subjected to batch fermentation to determine their capability to produce hydrogen $\left(\mathrm{H}_{2}\right)$ using synthetic starch wastewater as substrate in $60 \mathrm{~mL}$ serum bottles. Biogases of interest (hydrogen, carbon dioxide, methane) produced were analyzed using a Residual Gas Analyser (RGA), which is a mass spectrometry-based analytical system. A total of 52 isolates were obtained of which 13 of the isolates showed the ability to produce $\mathrm{H}_{2}$, with the NF6 isolate having the highest production of $6.85 \times 10^{-4} \%$ partial pressure [\% (pp)].

Conclusion, significance and impact study: From this study, culturable hydrogen-producing bacteria were successfully isolated from the three bovine manures. The results give an insight on the types of $\mathrm{H}_{2}$ producing bacteria present in the manure samples. These isolates will be useful for the further studies of $\mathrm{H}_{2}$ production using waste sources as substrates. The production of $\mathrm{H}_{2}$ by NF6 isolate will be optimized by varying parameters during the batch fermentation.
\end{abstract}

Keywords: Biohydrogen, bacteria, bovine manures, fermentation, Residual Gas Analyser (RGA)

\section{INTRODUCTION}

Over the years fossil fuel has been the main source of energy, as its discovery has brought about rapid development, industrialization and urbanization on a global scale. The production and utilization of these fossil fuels and its by-products has resulted in various environmental damages; aquatic pollution (mostly in the form of oil spillage) and the emission of greenhouse gases, such as carbon dioxide, nitrogen dioxide, methane and other chemicals. These gases are in turn responsible for the current global warming problems and climate change (Yokoi et al., 2001; Mohan et al., 2008). The estimated increase of energy consumption to over 54\% between the year 2001 to 2025 (Carere et al., 2008), the subsequent depletion of non-renewable fossil fuel resources, and the environmental problems caused has resulted in the rapid development of renewable and sustainable energy.

Hydrogen $\left(\mathrm{H}_{2}\right)$ has emerged as the cleanest of all renewable alternative energy sources, having the highest gravimetric energy content of $122 \mathrm{~kJ} / \mathrm{g}$ (Carere et al., 2008; Levin et al., 2004). It is a carbon-neutral energy carrier, and it has the possibility of replacing gasoline, diesel and ethanol due to its high energy conversion rate of about (50-70\%) via fuel cells (Zhang et al., 2007). Production of $\mathrm{H}_{2}$ is mainly from electrolysis, photolysis, and thermolysis of water, steam reformation and thermochemical methods of fossil fuel, thermal cracking of natural gas and coal gasification (Das and Veziroglu, 2001). $\mathrm{H}_{2}$ can also be as a result of the pyrolysis biomass to produce various gas mixtures.

Biological production of $\mathrm{H}_{2}$ is claimed to be an ideal, clean energy resource for the future and has attracted increasing interest due to its flexibility, low energy demand and environmental-friendliness (Kim et al., 2011). Biological method of production also facilitates waste treatment and recycling process, as various wastecontaining materials can be used (Das and Veziroglu, 2001).

Substrates which have been employed for $\mathrm{H}_{2}$ production, include agricultural produce containing starch or lignocellulosic content, such as corn, wheat, oilseeds, rice and corn starch (Carere et al., 2008); agro-industrial waste; sweet potato starch residue (Yokoi et al., 2001), waste from cheese industry (Carere et al., 2008), and pineapple waste (Wang et al., 2006; Lens et al., 2005); municipal waste and waste from paper mill; palm oil mill 
effluent (POME) (Ismail et al., 2010); sago starch in wastewater (Rafiani et al., 2011), wastewater from food and brewery industries (Kapdan and Kargi, 2006); animal fats and manure and dairy waste (Chaucheyras-Durand et al., 2010), due to their low cost and abundance. Theses wastes are rich in carbohydrates which can be easily broken down through different pathway by various microorganisms (Lateef et al., 2012). They are renewable, readily available and are most times constantly produced in bulk (Prakasham et al., 2009). Thus, the production of $\mathrm{H}_{2}$ from these wastes can go a long way in minimizing waste accumulation and help maintain a sustainable ecosystem (Lakshmidevi and Muthukumar, 2010).

The rumen compartment of herbivorous animals provides an anaerobic environment for numerous microfloras. The $\mathrm{pH}(5.5-5.8)$ at the rumen is maintained as a result of the rumination process making the environment favorable for fermentation (Russell and Rychlik, 2001; Gonzalez et al., 2012). Tonnes of cow manures are produced daily, and are disposed into landfills or applied on lands as a form of organic fertilizer which enhances the soil fertility (Swain and Ray, 2006). Anaerobic digestion of these manures is considered as a means of energy generation (Abubakar and Ismail, 2012). Till recent there are no concise explanation in the nature of the microbial population found in the rumen of cattle, which would affect the type of fermentation pathway and the end products obtained from the fermentation. Possible explanations are; the digestive capability of the rumen microbes and the type of feed given to the cattle (Wanapat et al., 2000; Khejomsart et al., 2011), fiber content and the ruminal degradability of the bacteria (Reynolds, 2006; Zebeli et al., 2010).

Fermentation pathway mostly leading to the production of acetate/butyrate favors the production of $\mathrm{H}_{2}$ as compared to that which produces propionate/lactic acid volatile fatty acids (VFA) (Antonopoulou et al., 2008). Metabolic pathways involved in these two types of bacteria are thus different. Fibre-digesting bacteria yield acetate and butyrate as its main metabolic volatile fatty acid (VFA) metabolites while the amylolytic bacteria mostly produce propionate. In the production of $\mathrm{H}_{2}$, pathways which lead to the production of acetate and butyrate as its main VFA are known to favor the production of $\mathrm{H}_{2}$ more than those which lead to the production of propionate (Matsumoto and Nishimura, 2007).

Bacterial species isolated from cow manures include: Selenomonas ruminantium, Megasphaera elsdenii (Wolin, 1975); ruminal bacteria Ruminococcus albus, Ruminococcus flavefaciens, Butyrivibrio fibrisolvens, Streptococcus bovis, Lactobacillus fermentens, Fibrobacter succinogenes (Russell and Rychlik, 2001), Paenibacillus polymixa (Kanso et al., 2011) and Bifidobacterium (Swain et al., 2006). Bacillus species such as; Bacillus cereus, B. subtilis, and B. licheniformis (Swain et al., 2006). Bacteria which have been involved in $\mathrm{H}_{2}$ production are mostly strict anaerobes belonging to the genera Clostridia (Chen et al.,
2008). Among the species include: Clostridium pasteurianum (Liu and Shen, 2004), C. thermolacticum from lactose (Collet et al., 2004; Carere et al., 2008), C. bifermentants (Wang et al., 2006), C. paraputrificum (Evvyernie et al., 2001) and C. buytricum (Yokoi et al., 2001).

Species from the genus Enterobactericeae also have the ability to produce $\mathrm{H}_{2}$ by metabolising glucose through the mixed acid or the 2,3-butanediol fermentation yielding $\mathrm{CO}_{2}$ and $\mathrm{H}_{2}$ from formic acid (Kumar and Das, 2001; Kapdan and Kargi, 2006). Enterobacter aerogenes (Fabiano and Perego, 2002) and E. cloacae IIT-BT 08 (Dutta et al., 2009) are the most widely studied species in the genus. Kumar and Das (2000) investigated the production of $\mathrm{H}_{2}$ from glucose substrate yielding $2.2 \mathrm{~mol}$ of $\mathrm{H}_{2} / \mathrm{mol}$ of glucose by $E$. cloacae IIT-BT 08. Trace amount of $\mathrm{H}_{2}$ production have been observed from Escherichia coli (Redwood et al., 2008). The genera Bacillus has also been reported to play a significant role in the fermentation process effectively producing $\mathrm{H}_{2}$ (Kotay and Das, 2007).

Thermophilic bacteria are also another group of organisms which has been studied for the production of $\mathrm{H}_{2}$. Thermoanaerobacterium saccharolyticum, $T$. thermosulfurigenes and thermophilic bacilli, isolated from hot spring has been used in biohydrogen production from wastewater containing starch (Rafiani et al., 2011). $\mathrm{H}_{2}$ production has also been reported by $T$. thermosaccharolyticum and Desulfotomaculum geothermicum (Shin et al., 2004), Rhodobacter capsulatus and Thermohydrogenium kirishis (Teplyakov et al., 2002). The ability to produce $\mathrm{H}_{2}$ has also been reported using some groups of aerobic bacteria, which include Aeromonas spp., Vibrio spp. and Pseudomonas spp. (Kapdan and Kargi, 2006).

This paper describes an investigation on the various hydrogen-producing bacteria isolated from three different bovine manure samples (dairy cow, feedlot cow and free grazing cow manures) using synthetic starch wastewater as substrate. Single colonies were successfully isolated and the results obtained give an insight on the types of bacteria found in the different manures. The isolates would be useful for further studies of $\mathrm{H}_{2}$ production using different waste sources as substrates.

\section{MATERIALS AND METHODS}

\section{Sample collection}

Samples of the cow manure were collected in a sterile 50 $\mathrm{mL}$ centrifuge tubes, from three different farm houses; dairy cow and free grazing cow farm houses located in Ulu Tiram and feedlot cow farm house located in Tebrau, Johor Bahru, Malaysia. Fresh manures (when possible) were used in order to minimize contamination by soil microorganisms. The samples were stored at $-20^{\circ} \mathrm{C}$ and kept till further use. 


\section{Isolation of hydrogen-producing bacteria}

\section{Isolation of facultative anaerobes}

The manure sample ( $1 \mathrm{~g})$ was serially diluted using distilled water to make up to $10^{-10}$ dilutions. Inoculation were then made on Nutrient Agar (NA) plates and incubated at $37^{\circ} \mathrm{C}$ for $24 \mathrm{~h}$. Colonies which appeared on the plate were sub-cultured onto NA plates to obtain single colonies which were then further stored at $-80{ }^{\circ} \mathrm{C}$ in $80 \%$ glycerol stock solution resulting to approximately $20 \%(\mathrm{v} / \mathrm{v})$. Bacterial colonies originating from this technique of isolation are named DC (dairy cow manure), FDC (feedlot cow manure) and FGC (free grazing cow manure).

\section{Isolation of strict anaerobes}

Hungate technique was employed for the isolation of strict anaerobes (Hungate, 1969). Anaerobic environment were created in the media by purging with nitrogen gas in order to remove the oxygen present. Oxygen removal is detected by color change from green to pink as a result of the indicator dye (Resazurin) initially added to the media. The Reinforced Clostridium Media (RCM) and Nutrient Broth (NB) were cooled to $50^{\circ} \mathrm{C}$. Each sample $(1 \mathrm{~g})$ were aseptically transferred into $70 \mathrm{~mL}$ serum bottles of both $\mathrm{RCM}$ broth and NB and incubated at $37{ }^{\circ} \mathrm{C}$ for $48 \mathrm{~h}$. Prior to the inoculation into RCM broth, $1.5 \%(\mathrm{v} / \mathrm{v})$ of glucose solution and $5 \%(\mathrm{v} / \mathrm{v})$ of vitamin solution were added to the media using a needle and syringe. Vitamin solution used had the following composition in $\mathrm{g} / 100 \mathrm{~mL} ; 1 \mathrm{~g}$ of cysteine, $2.0 \mathrm{mg}$ of $\rho$-aminobenzenoic acid and $1.6 \mathrm{mg}$ of biotin.

Inoculated samples were then serially diluted in NB and RCM broth followed by inoculation into their respective agar. The rolling-tube method was employed for the inoculation into the RCM agar. In this method, samples were inoculated into the respective agar, swirled briefly and rolled on ice to facilitate the solidifying of the agar onto the sides of the serum bottles. Rolling-tube method of inoculation is mostly used in situations where streak plate method on solid agar media cannot be employed. Media used for isolation is heated and oxygen is driven off by displacing it with nitrogen. Several dilutions are made on the inoculum suspension and mixed with the media in order to obtain cultures with appropriately-spaced colonies (Hungate and Macy, 1973).

Bacterial colonies originating from this technique of isolation are named and differentiated based on the media used: ND (dairy cow manure), NG (feedlot cow manure) and NF (free grazing cow manure) from isolation using NB; RD (dairy cow manure), RG (feedlot cow manure) and $R F$ (free grazing cow manure) from isolation using RCM.

\section{Characterizations of the isolates and biochemical analysis}

The facultative anaerobe isolates were subjected to sugar fermentation test using Triple Sugar Iron Agar (TSIA) medium, to determine the ability of the isolates to ferment sugars and produce gas. TSIA, a differential medium which is mostly used to differentiate enteric bacteria based on their ability to ferment sugars and reduce sulfur. The media contains three different types of sugars (lactose, sucrose and a small amount of glucose); upon fermentation of any of these sugars a color change is observed in the medium (red-yellow) as a result of the phenol red $\mathrm{pH}$ indicator. The medium can also be used to determine the ability of an organism to produce gas during the fermentation process, this is observed as cracks in the medium or the entire slant or agar would be raised above the bottom of the test tube. Observation made in the media was recorded accordingly.

Biochemical tests are usually done to determine the genus of an unknown bacterial species. The facultative isolates screened for the production of gas subjected to; citrate utilization test, urease test, indole production test, nitrate reduction test and catalase test, according to standard procedure. Gram staining was performed on both facultative and strict anaerobic isolates. Results from the analysis were used to find the closest match and to assign the bacterial signature with a known bacterial genus according to Bergey's Manual of Determinative Bacteriology (Breed et al., 1957).

\section{$\mathrm{H}_{2}$ production assay}

The ability of an isolate to produce $\mathrm{H}_{2}$ was determined by subjecting the colonies to batch fermentation using synthetic starch wastewater as the substrate. The wastewater solution was prepared in the following compositions (in $\mathrm{mg} / \mathrm{L}$, unless stated): starch 70; peptone 90; yeast extract 12; ammonium chloride 96; $\mathrm{MgSO}_{4} \cdot 7 \mathrm{H}_{2} \mathrm{O}$ 24; $\mathrm{MnSO}_{4} \cdot 5 \mathrm{H}_{2} \mathrm{O} 2.16 ; \mathrm{FeSO}_{4} \cdot 7 \mathrm{H}_{2} \mathrm{O}$ 10; $\mathrm{CaCl}_{2} \cdot 2 \mathrm{H}_{2} \mathrm{O} 2.4 ; \mathrm{ZnSO}_{4} \cdot 7 \mathrm{H}_{2} \mathrm{O} 0.106 ; \mathrm{CoCl}_{2} \cdot 6 \mathrm{H}_{2} \mathrm{O} 52.6$ $\mu \mathrm{g}$; $\mathrm{CuSO}_{4} \cdot 5 \mathrm{H}_{2} \mathrm{O} 4.5 \mu \mathrm{g} ; 0.5 \mathrm{M}$ potassium phosphate buffer, pH 7.0 \pm 0.2 (Klatt and LaPara, 2002; Chen, 2000). The solution was flushed with nitrogen gas, and then 40 $\mathrm{mL}$ was dispensed into $60 \mathrm{~mL}$ serum bottle, capped with rubber stopper and sealed with aluminium cover. Bacterial cells were grown overnight in NB and RCM broth and $10 \%$ of the culture was used as inoculum to inoculate the fermentation medium (Khamaiseh et al., 2012). A Buchner flask (150 mL) was connected to the serum bottles during the fermentation process to collect the gases produced. The flask was initially vacuumed using a vacuum pump at 0.7 bar for 3 min before connecting to the serum bottle. Both the serum bottle and flask was incubated at $37^{\circ} \mathrm{C}$ for $24 \mathrm{~h}$. Clostridium sp. was used as positive control for $\mathrm{H}_{2}$ production.

Gases produced were then analyses using the Residual Gas Analyser Model Cirrus 2 (MKS Instruments, MA, USA), which is equipped with a pump to vacuum the gases produced during Buchner flask into the machine. 
$\mathrm{H}_{2}, \mathrm{CO}_{2}$ and $\mathrm{CH}_{4}$ content were recorded as partial pressure (Torr) of the percentage of each of the gas presents.

\section{RESULTS AND DISCUSSION}

A total of 31 facultative anaerobe colonies were isolated.
From the isolates obtained, dairy and feedlot cow manures gave 12 and 11 colonies respectively, while the free grazing cow manure yielded 8 colonies, as shown in Table 1. A total of 21 strict anaerobe colonies were isolated with 7 colonies each from the manure samples. Eight colonies were isolated from NB and 13 colonies from RCM Broth, as shown in Table 2.

Table 1: Facultative and strict anaerobic bacteria isolates obtained from the three manure samples.

\begin{tabular}{|c|c|c|c|c|c|}
\hline \multirow[b]{2}{*}{ Types of isolates } & \multirow[b]{2}{*}{ Types of media } & \multicolumn{3}{|c|}{ Types of manure samples } & \multirow[b]{2}{*}{ Total } \\
\hline & & Dairy cow & Feedlot cow & Free grazing cow & \\
\hline Facultative & NB & 12 & 11 & 8 & 31 \\
\hline \multirow{2}{*}{ Strict } & NB & 3 & 2 & 3 & 8 \\
\hline & RCM & 4 & 5 & 4 & 13 \\
\hline
\end{tabular}

Table 2: Sugar fermentation test for the facultative anaerobes.

\begin{tabular}{|c|c|c|c|}
\hline \multirow[t]{2}{*}{ Isolates } & \multicolumn{3}{|c|}{ Reactions in the TSIA medium } \\
\hline & Butt* $^{*}$ & Slope* & $\mathrm{H}_{2} \mathrm{~S}$ production ${ }^{\S}$ \\
\hline DC10(2)1 & $\mathrm{Y}$ & $\mathrm{Y}$ & - \\
\hline DC10(2)2 & $\mathrm{Y}$ & $Y G$ & - \\
\hline DC10(2)3 & $\mathrm{Y}$ & $\mathrm{Y}$ & - \\
\hline DC10(2)4 & $\mathrm{Y}$ & Y & - \\
\hline DC10(3) 1 & Y & $\mathrm{Y}$ & - \\
\hline $\mathrm{DC} 10(3) 2$ & Y & $Y G$ & - \\
\hline DC10(3)3 & $\mathrm{Y}$ & YG & - \\
\hline DC10(3) 4 & $\mathrm{R}$ & $\mathrm{R}$ & - \\
\hline DC10(4)1 & Y & YG & - \\
\hline DC10(4)2 & Y & $\mathrm{Y}$ & - \\
\hline $\mathrm{DC} 10(4) 3$ & $\mathrm{Y}$ & $Y G$ & - \\
\hline $\mathrm{DC} 10(5) 1$ & $Y$ & $\mathrm{Y}$ & - \\
\hline FDC10(2)1 & $\mathrm{Y}$ & Y & - \\
\hline FDC10(3) 1 & Y & Y & - \\
\hline FDC10(3)2 & $Y$ & $Y$ & - \\
\hline FDC10(4)1 & $Y$ & ${ }^{1} \mathrm{R}$ & - \\
\hline FDC10(4)2 & $Y$ & $Y$ & - \\
\hline FDC10(4)3 & $\mathrm{Y}$ & $Y$ & - \\
\hline FDC10(4)4 & $Y$ & $Y$ & - \\
\hline FDC10(4)5 & $Y$ & $Y$ & - \\
\hline FDC10(5)1 & $Y$ & $Y$ & - \\
\hline FDC10(5)2 & $Y$ & $Y$ & - \\
\hline FDC10(6) 1 & $Y$ & $Y$ & - \\
\hline FGC10(2) 1 & $Y$ & $Y G$ & - \\
\hline FGC10(3)2 & $Y$ & YG & - \\
\hline FGC10(3) 1 & $\mathrm{Y}$ & $\mathrm{Y}$ & - \\
\hline FGC10(3)3 & $Y$ & YG & - \\
\hline FGC10(4) 1 & $Y$ & $Y G$ & - \\
\hline FGC10(4)2 & $Y$ & $Y$ & - \\
\hline FGC10(4)3 & $Y$ & $\mathrm{Y}$ & - \\
\hline FGC10(4)4 & $Y$ & $Y G$ & - \\
\hline
\end{tabular}

DC, dairy cow manure sample; FDC, feedlot cow manure sample; FGC, free grazing cow manure sample; *Y, medium changed color to yellow (signifies acid production); * $Y G$, medium changed color to yellow, gas is produced; $1 \mathrm{R}$, no color change in the medium; $\S+$, blackening of medium. 


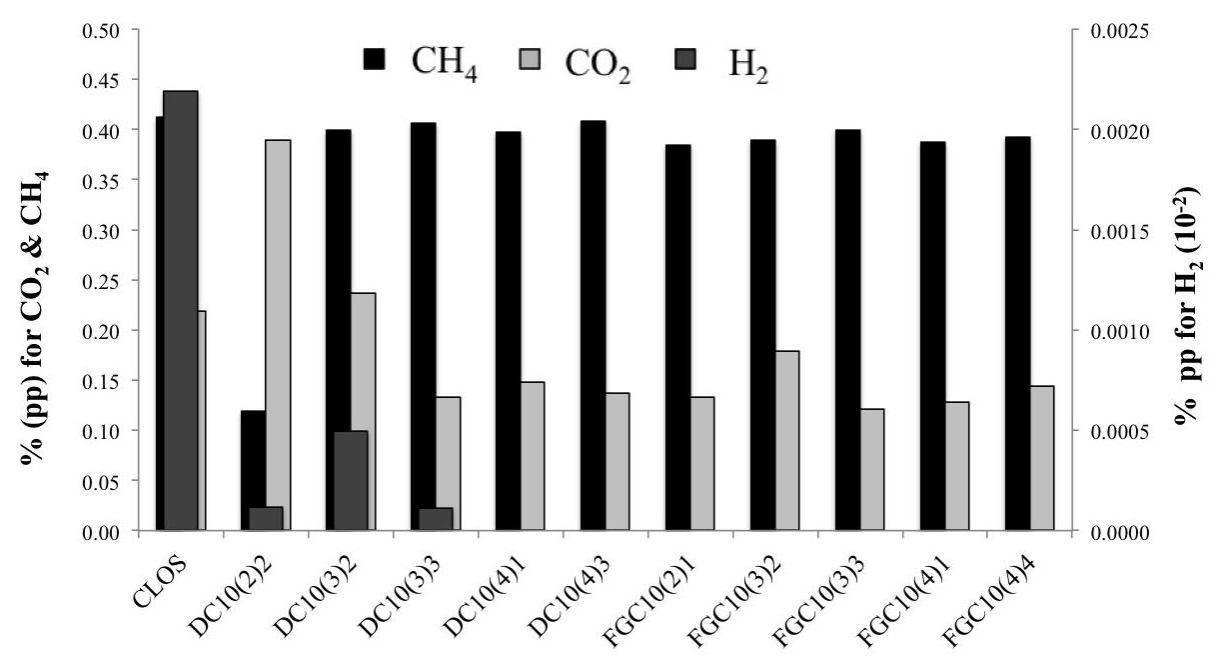

Figure 1: Gas production $\left(\mathrm{H}_{2}, \mathrm{CO}_{2}\right.$ and $\left.\mathrm{CH}_{4}\right)$ by facultative anaerobes. CLOS, positive control; DC, dairy cow manure sample; FGC, free grazing cow manure sample.

The 31 facultative anaerobe colonies were first subjected to the sugar fermentation test to screen for gas production using TSIA as medium. It was found that all (except two) colonies have the ability to ferment the carbohydrates (glucose, sucrose and lactose) present in the TSIA medium. Ten of the colonies, five from dairy cow manure and five colonies from free grazing cow manure have the ability to produce gas (Table 2). None of the colonies from feedlot cow manure showed the ability of gas production. Gas produced in the TSIA media was detected through the presences of bubbles, cracks, pushing up of agar from the bottom or from the side of the agar.

Analysis of $\mathrm{H}_{2}$ production using Residual Gas Analyser (RGA) by measuring the pressure (Torr) of gases present in the Buchner collecting flasks showed that 3 facultative anaerobe isolates produced $\mathrm{H}_{2}$ at a detectable level (Figure 1). They are colonies DC10(2)2, DC10(3)2 and DC10(3)3. Results obtained are in percentage of partial pressure [\%(pp)] of the individual gases $\left(\mathrm{H}_{2}, \mathrm{CO}_{2}\right.$ and $\left.\mathrm{CH}_{4}\right)$ produced.

All of the facultative anaerobe colonies appear circular in form, having entire margins with sizes ranging from $0.2-0.7 \mathrm{~cm}$ in diameter. The colonies had flat, convex, raised and punctiform elevation, opaque characteristics, cream in color, with smooth surfaces. In order to identify the identities of the facultative anaerobe colonies that show $\mathrm{H}_{2}$ production, biochemical tests were performed for partial identification. Table 3 summarizes the results obtained. The biochemical tests showed that the strains are able to reduce nitrate, produce indole and show positive catalase test, but were unable to utilize citrate as a growth substrate nor produce urease. DC10(2)2 and DC10(3)3 are Gram negative bacilli while DC10(3)2 is a Gram negative coccus. From the biochemical tests results obtained (Table 3 ), it can be suggested that the facultative anaerobes might belong to the genus Enterobacteriaceae, Aeromonas, Veillonella and Acinetobacter.

Analysis of $\mathrm{H}_{2}$ production by the strict anaerobe colonies shows that 2 strict anaerobes isolated using RCM (RG4 and RF4) (Figure 2) are able to produce $\mathrm{H}_{2}$ via starch fermentation, and all strict anaerobe colonies isolated using NB are able to produce $\mathrm{H}_{2}$ (Figure 3).

For partial identification, Table 4 shows the result of biochemical tests (Gram stain and catalase test) performed on strict anaerobes. Catalase tests are negative for all the strict anaerobes, isolates from RCM medium are both Gram positive cocci while those from NB are either Gram positive bacilli (ND5, ND6, ND7, NG5, NF6, NF7), Gram negative bacillus (NG6) or Gram positive coccus (NG7).

Table 3: Biochemical tests for the facultative anaerobe colonies. DC: dairy cow manure.

\begin{tabular}{|c|c|c|c|c|c|c|}
\hline \multirow{2}{*}{ Isolates } & \multicolumn{6}{|c|}{ Biochemical tests } \\
\hline & Gram staining* & Citrate utilisation & Urease & Indole & Catalase & Nitrate reduction \\
\hline DC10(2)2 & (-) bacillus & - & - & + & + & + \\
\hline DC10(3)2 & $(-)$ coccus & - & - & + & + & + \\
\hline DC10(3)3 & (-) bacillus & - & - & + & + & + \\
\hline
\end{tabular}




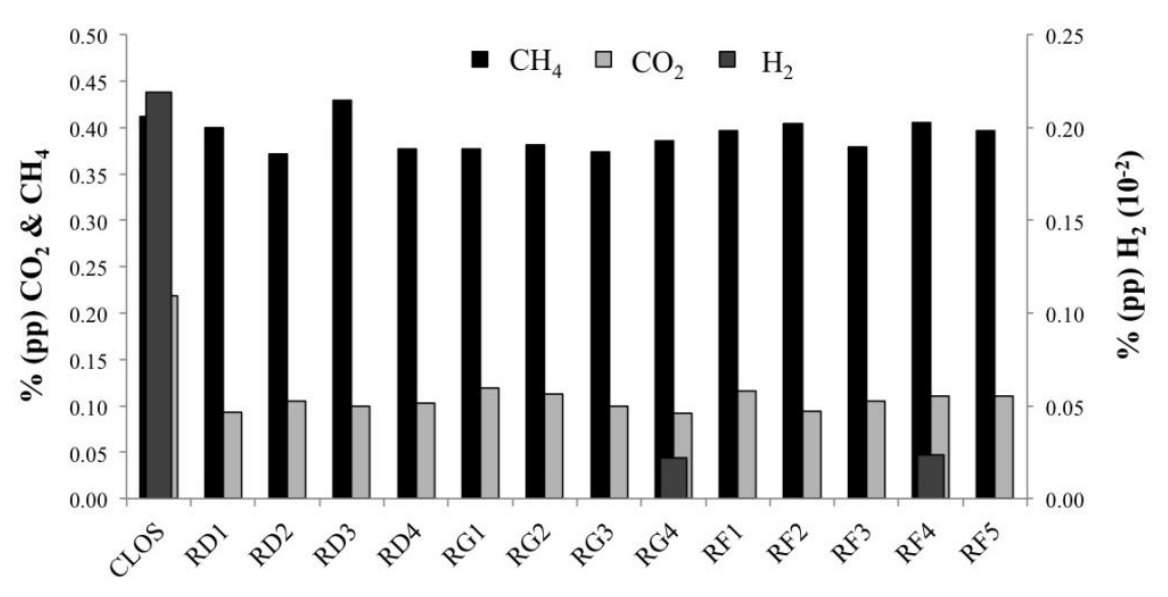

Figure 2: Gas production $\left(\mathrm{H}_{2}, \mathrm{CO}_{2}\right.$ and $\left.\mathrm{CH}_{4}\right)$ by strict anaerobe colonies isolated using RCM medium. CLOS, positive control; RD, dairy cow manure sample; RG, feedlot cow manure sample; RF, free grazing cow manure sample.

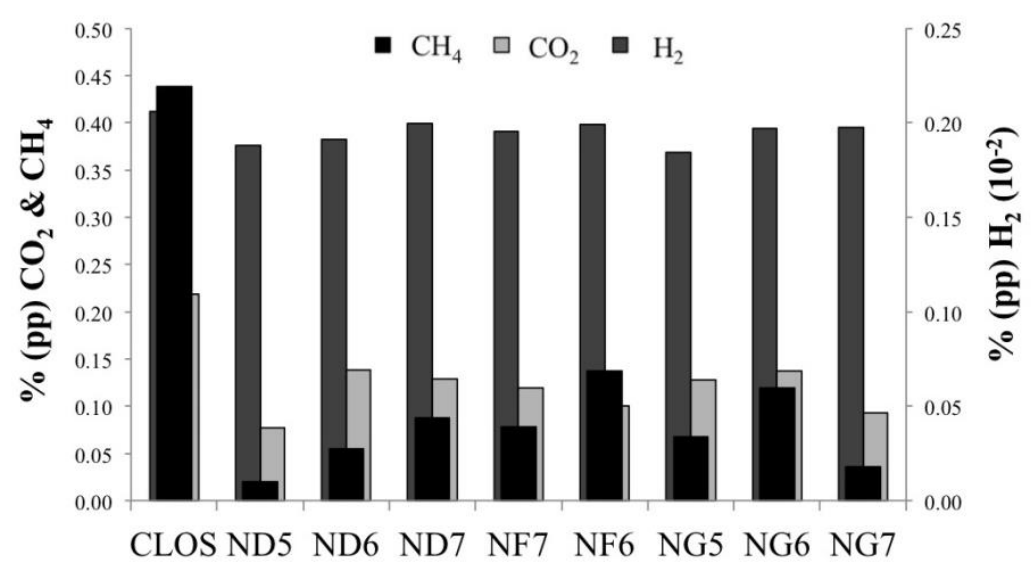

Figure 3: Gas production $\left(\mathrm{H}_{2}, \mathrm{CO}_{2}\right.$ and $\left.\mathrm{CH}_{4}\right)$ by strict anaerobe colonies isolated using NB medium. CLOS, positive control; ND, dairy cow manure sample; NG, feedlot cow manure sample; NF, free grazing cow manure sample.

Characterization and identification of anaerobes to genus level using biochemical tests are usually challenging to be carried out and are limited to certain test. The results obtained are also not as reliable as compared to the results obtained for facultative anaerobes. This could be due to the biochemical tests that are usually done in the presence of oxygen. Classification of strict anaerobes might require additional biochemical tests such as determination of metabolic end product [usually analyzed by gas liquid chromatography (GLC)], spore formation for some anaerobes, and in some cases determination of antibiotic resistance or susceptibility.
Figure 4 shows the $\mathrm{H}_{2}$ production ability by colonies from both facultative anaerobes and strict anaerobes, for comparison purposes. It can be seen that NF6, isolated from the feedlot cow manure, showed the highest $\mathrm{H}_{2}$ production of $0.0685 \times 10^{-2} \%$ (pp) among all the isolates subjected to fermentation.

$\mathrm{H}_{2}$ production analysis showed that $\mathrm{H}_{2}$ is detected in most of the bacteria isolated from dairy cow and free grazing cow manure samples. This could be attributed to the type of microbes found in the rumen of the different types of cattle and the fermentation pathway employed by them. Among the factors known to contribute to this is the types of cattle feed, which determine the type of bacteria. 
Table 4: Biochemical tests for the strict anaerobes.

\begin{tabular}{ccc}
\hline \multirow{2}{*}{ Isolates } & \multicolumn{2}{c}{ Biochemical tests } \\
\cline { 2 - 3 } & Gram staining* & Catalase \\
\hline RG4 & $(+)$ coccus & - \\
RF4 & $(+)$ coccus & - \\
ND5 & $(+)$ bacillus & - \\
ND6 & $(+)$ bacillus & - \\
ND7 & $(+)$ bacillus & - \\
NG5 & $(+)$ bacillus & - \\
NG6 & $(-)$ bacillus & - \\
NG7 & $(+)$ coccus & - \\
NF6 & $(+)$ bacillus & - \\
NF7 & $(+)$ bacillus & - \\
\hline
\end{tabular}

$R G$, feedlot cow manure sample (RCM isolation); RF, free grazing cow manure sample (RCM isolation); ND, dairy cow manure sample (NB isolation); NG, feedlot cow manure sample (NB isolation); NF, free grazing cow manure sample (NB isolation).

*Gram staining, (Gram positive/negative) (cell shape); +, Positive test results; -, Negative test results.

Note: Other tests are not possible to be performed on the strict anaerobes due to the nature of the tests that usually requires aerobic environment.

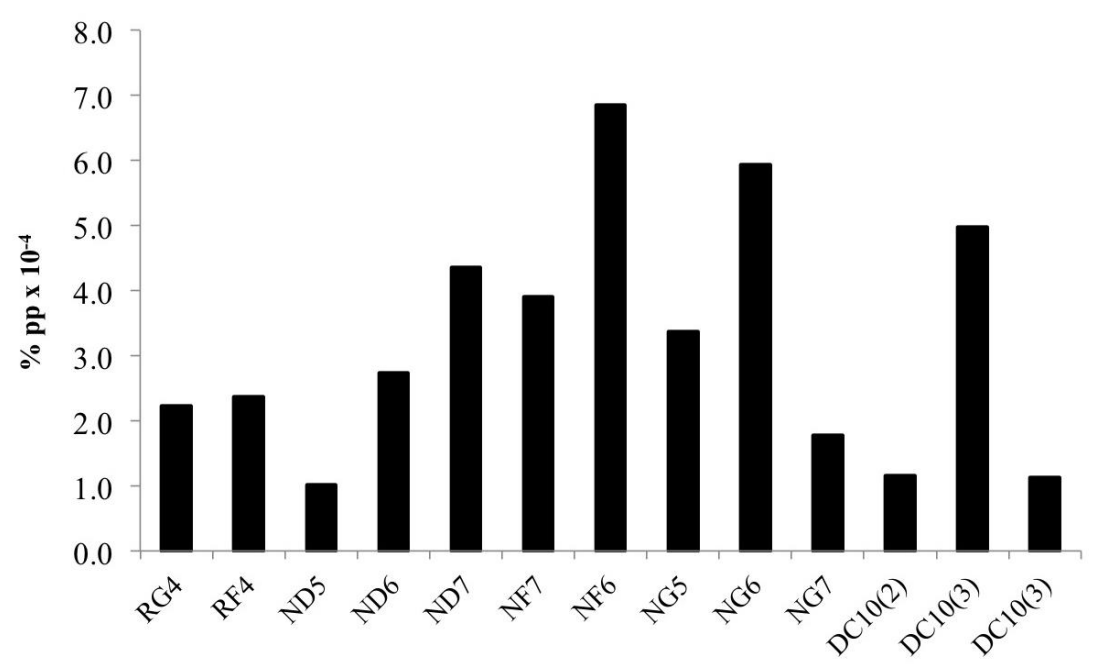

Figure 4: Comparison of $\mathrm{H}_{2}$ production by the different isolates. $\mathrm{RG}$, feedlot cow manure sample (strict anaerobe, RCM isolation); RF, free grazing cow manure sample (strict anaerobe, RCM isolation); ND, dairy cow manure sample (strict anaerobe, NB isolation); NF, free grazing cow manure sample (strict anaerobe, NB isolation); NG, feedlot cow manure sample (strict anaerobe, NB isolation); DC, dairy cow manure sample (facultative anaerobe).

that colonize the rumen, as reported by others (Khejornsart et al., 2011). Rumen microorganisms are mainly consisting of cellulolytic bacteria, other than anaerobic fungi and protozoa. We observed that during sampling, the different farms (dairy, feedlot and freegrazing) fed different feed to the cows. Diet for dairy cows mainly consists of watermelon and its waste, while for feedlot cows it is mainly pineapple waste. Free-grazing cows feed on grass. Although the actual fiber content of these feeds is not known, it is possible that they affect the microbial population in the rumen, particularly the cellulolytic bacterial population.
The different types of feed substrate can then in turn affect the $\mathrm{pH}$ of the rumen (Calsamiglia et al., 2008). Previous studies have shown that maximum $\mathrm{H}_{2}$ yield is obtained at an acidic or slightly acidic $\mathrm{pH}$ (Kumar and Das, 2000; Khanna et al., 2011). Average rumen fermentation phase has been shown to be at $\mathrm{pH} 6.0$ to 6.2 (Krause and Oetzel, 2006). Khanna and co-workers (2011) observed that the optimum operational $\mathrm{pH}$ for Enterobacter cloacae strain IIT-BT08 to yield the highest

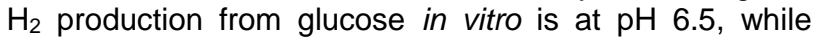
Citrobacter freundii strain CWB1952 has been shown to produce $\mathrm{H}_{2}$ at $\mathrm{pH} 5.9$ (Hamilton et al., 2010), using batch 
method with glucose as substrate. These demonstrate that for optimum $\mathrm{H}_{2}$ production by bacteria, a slightly acidic $\mathrm{pH}$ is required. As different types of substrate may contribute to different $\mathrm{pH}$ conditions in the rumen, this explains the differing populations of $\mathrm{H}_{2}$-producing bacteria in the three cow types investigated.

\section{CONCLUSION}

Several bacterial colonies have successfully been isolated from the 3 different cow manures, with dairy cow manure samples giving the most hydrogen-producing bacteria. From the results of the biochemical test and morphological characteristics obtained, partial identification suggests that the facultative anaerobe isolates might belong to the genus Enterobacteriaceae, Aeromonas, Acinetobacter and Veillonella while the strict anaerobes require further analysis for identification. It was found that the manures of dairy and free grazing cows produce more hydrogen-producing bacteria, compared to the feedlot cow, probably due to the different feed composition that affects the microbial ecosystem in the rumen of the animals.

\section{ACKNOWLEDGEMENT}

The authors would like to acknowledge Dr Tuan Amran Tuan Abdullah from the Faculty of Chemical Engineering, UTM for assistance with RGA, and the Johor State Veterinary Service Department for assistance with manure sampling. This project is supported by the New Academic Staff (NAS) Grant awarded by UTM to M.F.AW.

\section{REFERENCES}

Abubakar, B. S. U. and Ismail, N. (2012). Anaerobic digestion of cow dung for biogas production. ARPN Journal of Engineering and Applied Sciences 7(2), 169-172.

Antonopoulou, G., Stamatelatou, K., Venetsaneas, N., Kornaros, M. and Lyberatos, G. (2008). Biohydrogen and methane production from cheese whey in a two-stage anaerobic process. Industrial and Engineering Chemistry Research 47(15), 52275233.

Breed, R. S., Murray, E. G. D. and Smith, N. R. (1957). Bergey's Manual of Determinative Bacteriology. $7^{\text {th }}$ edn. Waverly Press Inc., USA. pp. 281-694.

Carere, R. C., Sparling, R., Cicek, N. and Levin, D. B. (2008). Third generation biofuels via direct cellulose fermentation. International Journal of Molecular Sciences $9(7), 1342-1360$.

Calsamiglia, S., Cardozo, P. W., Ferret, A. and Bach, A. (2008). Changes in rumen microbial fermentation are due to a combined effect of type of diet. Journal of Animal Science 86(3), 702-711.

Chaucheyras-Durand, F., Masseglia, S., Fonty, G. and Forano, E. (2010). Influence of the composition of the cellulolytic flora on the development of hydrogenotrophic microorganisms, hydrogen utilization, and methane production in the rumens of gnotobiotically reared lambs. Applied and Environmental Microbiology 76(24), 7931-7937.

Chen, S-D., Lee, K-S., Lo, Y-C., Chen, W-M., Wu, J-F., Lin, C-Y. and Chang, J-S (2008). Batch and countinous biohydrogen production from starch hydrolysate by Clostridium species. International Journal of Hydrogen Energy 33(7), 1803-1812.

Collet, C., Adler, N., Schwitzguebel, J-P. and Peringer, P. (2004). Hydrogen production by Clostridium thermolacticum during continous fermentation of lactose. International Journal of Hydrogen Energy 29(14), 1479-1485.

Das, D. and Veziroglu, T. N. (2001). Hydrogen production by biological processes: A survey of literature. International Journal of Hydrogen Energy 26(1), 13-28.

Dutta, T., Das, A. K. and Das, D. (2009). Purification and characterization of [Fe]-hydrogenase from high yielding hydrogen-producing strain, Enterobacter cloacae IIT-BT08 (MTCC 5373). International Journal of Hydrogen Energy. 34(17), 7530-7537.

Evvyernie, D., Morimoto, K., Karita, S., Kimura, T., Sakka, K. and Ohmiya, K. (2001). Conversion of chitinous waste to hydrogen gas by Clostridium paraputrificum M-21. Journal of Bioscience and Bioengineering 91(4), 339-43.

Fabiano, B. and Perego, P (2002). Thermodynamic study and optimization of hydrogen production by Enterobacter aerogenes. International Journal of Hydrogen Energy 27, 149-156.

Gonzalez, L. A., Manteca, X., Calsamiglia, S., Schwartzkopf-Genswein, K. S. and Ferret, A. (2012). Ruminal acidosis in feedlot cattle: Interplay between feed ingredients, rumen function and feeding behavior (A review). Animal Feed Science and Technology 172(1-2), 66-79.

Hamilton, C., Hiligsmann, S., Beckers, L., Masset, J., Wilmotte, A. and Thonart, P. (2010). Optimisation of culture conditions for biological hydrogen production by Citrobacter freundii CWB1952 in batch, sequenced-batch and semicontinuous operating mode. International Journal of Hydrogen Energy 35, 1089-1098.

Chen, H. (2000). ATP as an indicator of biomass activity in thermophilic upflow anaerobic sludge blanket reactor. Journal of Environmental Sciences 12(3), 380-384.

Hungate, R. E. (1969). A roll-tube method for cultivation of strict anaerobes. In: Methods in Microbiology. Norris, J. R. and Ribbons, D. W. (eds.). Acadmic Press. 3B, 117-132.

Hungate, R. E. and Macy, J. (1973). The roll-tube method for cultivation of strict anaerobes. In: Modern Methods in the Study of Microbial Ecology: Proceedings of a Symposium. Roswall, T. (ed.). Statens natuvetenskapliga forskningsrad, Michigan. pp. 123-126. 
Ismail, I., Hassan, M. A., Rahman, N. A. and Soon, C. S. (2010). Thermophilic biohydrogen production from palm oil mill effluent (POME) using suspended mixed culture. Biomass and Bioenergy 34(1), 42-47.

Kanso, S., Dasri, K., Tingthong, S. and Watanapokasin, R. Y. (2011). Diversity of cultivable hydrogen-producing bacteria isolated from agricultural soils, waste water sludge and cow dung. International Journal of Hydrogen Energy 36(14), 8735-8742.

Kapdan, I. K. and Kargi, F. (2006). Bio-hydrogen production from waste materials. Enzyme and Microbial Technology 38(5), 569-582.

Khamaiseh, E. I., Kalil, M. S., Dada, O., El-Shawabkeh, I. and Yusoff, M. W. (2012). Date fruit as carbon source in RCM-modified medium to produce biobutanol by Clostridium acetobutylicum NCIMB 13357. Journal of Applied Science 12(11), 11601165.

Khanna, N., Kotay, S. M., Gilbert, J. J. and Das, D. (2011). Improvement of biohydrogen production by Enterobacter cloacae IIT-BT08 under regulated $\mathrm{pH}$. Journal of Biotechnology 152(1-2), 9-15.

Khejornsart, P., Wanapat, M. and Rowlinson, P. (2011). Diversity of anaerobic fungi and rumen fermentation characteristics in swamp buffalo and beef cattle fed on different diets. Livestock Science 139, 230-236.

Kim, J. Y., Jo, B. H. and Cha, H. J. (2011). Production of biohydrogen by heterologous expression of oxygentolerant Hydrogenovibrio marinus [NiFe]hydrogenase in Escherichia coli. Journal of Biotechnology 155(3), 312-319.

Klatt, C. G. and LaPara, T. M. (2002). Aerobic biological treatment of synthetic municipal wastewater in membrane-coupled bioreactors. Biotechnology and Bioengineering 82(3), 313-320.

Kotay, S. M. and Das, D. (2007). Microbial hydrogen production with Bacillus coagulans IIT-BT S1 isolated from anaerobic sewage sluge. Bioresource Technology 98(6), 1183-1190.

Krause, K. M. and Oetzel, G. R. (2006). Understanding and preventing subacute ruminal acidosis in dairy herds: A review. Animal Feed Science and Technology 126, 215-236.

Kumar, N. and Das, D. (2000). Enhancement of hydrogen production by Enterobacter cloacae IIT-BT 08. Process Biochemistry 35(6), 589-593.

Kumar, N. and Das, D. (2001). Countinous hydrogen production by immobilized Enterobacter cloacae IIT. BT08 using lignocellulosic materials as solid matrices. Enzyme and Microbial Technology 29(4-5), 280-287.

Lakshmidevi, R. and Muthukuar, K. (2010). Enzymatic saccharification and fermentation of paper pulp industry effluent for bioydrogen production. International Journal of Hydrogen Energy 35(8), 3389-3400.

Lateef, S. A., Beneragama, N., Yamashiro, T., Iwasaki, M., Ying, C. and Umetsu, K. (2012). Biohydrogen production from co-digestion of cow manure and waste milk under therophilic temperature. Bioresource Technology 110, 251-257.

Lens, P., Westermann. P., Haberbauer, $M$. and Moreno, A. (2005). Biofuels for Fuel Cells: Renewable Energy from Biomass Fermentation. IWA Publishing, London.

Levin, D. B., Pitt, L. and Love, M. (2004). Biohydrogen production: Prospect and limitation to practical application. International Journal of Hydrogen Energy 29(2), 173-185.

Liu, G. and Shen, J. (2004). Effects of culture and medium conditions on hydrogen production from starch using anaerobic bacteria. Journal of Bioscience and Bioengineering 98(4), 251-256.

Matsumoto, M. and Nishimura, Y. (2007). Hydrogen production by fermentation using acetic acid and lactic acid. Journal of Bioscience and Bioengineering 103(3), 236-241.

Mohan, S. V., Mohanakrishma, G., Reddy, S. S., Raju, B. D., Rao, K. S. R. and Sarma, P. N. (2008). Selfimmobilization of acidogenic mixed consortia on mesoporous material (SBA-15) and activated carbon to enhance fermentative hydrogen production. International Journal of Hydrogen Energy 33(21), 6133-6142.

Prakasham R. S., Brahmaiah, P., Sathish, T. and Sambasiva Rao, K. R. S. (2009). Fermentative biohydrogen production by mixed anaerobic consortia: Impact of glucose to xylose ratio. International Journal of Hydrogen Energy 34, 93549361.

Rafiani, H., Tsuyoshi, I., Sompang, O-T. and Liliek, S. (2011). Biohydrogen production from sago starch in wastewater using an enriched thermophilic mixed culture from hot spring. International Journal of Hydrogen Energy 36(21), 14162-14171.

Redwood, M. D., Mikheenko, I. P., Sargent, F. and Macaskie, L. E. (2008). Dissecting the roles of Escherichia coli hydrogenases in biohydrogen production. Federation of European Micro-biological Societies (FEMS) Microbiology Letters 2778(1), 4855.

Reynolds, C. K. (2006). Production and metabolic effects of site of starch digestion in dairy cattle. Animal Feed Science and Technology 130(1-2), 78-94.

Russell, J. B. and Rychlik, J. L. (2001). Factors that alter rumen microbial ecology. Science 292 (5519), 1119-1122.

Shin, H-S., Youn, J-H. and Kim, S-H. (2004). Hydrogen production from food waste in anaerobic mesophilic and thermophilic conditions. Journal of Environmental Management 69, 149-156.

Swain, M. R. and Ray, R. C. (2006). Biocontrol and other beneficial activities of Bacillus subtilis isolated from cow dung microflora. Microbiological Research 164(2), 121-130.

Swain, M. R., Kar, S., Padmaja, G. and Ray, R. C. (2006). Partial characterization and optimization of production of extracellular $\alpha$-amylase from Bacillus 
subtilis isolated from culturable cow dung microflora. Polish Journal of Microbiology 55(4), 289-296.

Teplyakov, V. V., Gassanova, L. G., Sostina, E. G., Slepova, E. V., Modigell, M. and Netrusov, A. I. (2002). Lab-scale bioreactor integrated with active membrane system for hydrogen production: Experience and prospects. International Journal of Hydrogen Energy 27(11-12), 1149-1115.

Wanapat, M., Ngarmsang, A., Korkhuntot, S., Nontaso, N., Wachirapakorn, C., Beakes, G. and Rowlinson, P. (2000). A comparative study on the rumen microbial population of cattle and swamp buffalo raised under traditional village conditions in the northeast of Thailand. Asian-Australian Journal of Animal Science 13(7), 918-921.

Wang, C-H., Lin, P-J. and Chang, J-S. (2006). Fermentative conversion of sucrose and pineapple waste into hydrogen gas in phosphate-buffered culture seeded with municipal sewage sludge. Process Biochemistry 41(6), 1353-1358.

Wolin, M. J. (1975). Interaction between the bacterial species in the rumen. In: Digestion and metabolism in the Ruminant. MacDonalds, J. W. and Warner, A. C. I. (eds). University of new England, Armidale, Australia. pp. 134-148.

Yokoi, H., Saitsu, A., Uchida, H., Hirose, J., Hayashi, S. and Takasaki, Y. (2001). Microbial hydrogen production from sweet potato starch residue. Journal for Bioscience and Bioengineering 91(1), 58-63.

Zebeli, Q., Mansmann, D., Steingass, H. and Ametaj, B. N. (2010). Balancing diets for physically effective fibre and ruminally degradable starch: A key to lower the risk of sub-acute rumen acidosis and improve productivity of dairy cattle. Livestock Science 127(1), 1-10.

Zhang, Y. H., Evans, B. R., Mielenz, J. R., Hopkins, R. C. and Adams, M. W. (2007). High-yield hydrogen production from starch and water by a synthetic enzyme pathway. PLoS One 2(5), 1-6. 